\section{Heteronormativity, Masculinity and Prejudice in Mobile Apps: The Case of Grindr in a Brazilian City}

\author{
Luiz Alex Silva Saraiva ${ }^{1}$ \\ saraiva@face.ufmg.br|@0000-0001-5307-9750 \\ Leonardo Tadeu dos Santos ${ }^{1}$ \\ leonardotadeu17@gmail.com| (D)0000-0003-1909-2585 \\ Jefferson Rodrigues Pereira ${ }^{1}$ \\ jeffersonrodrigues@live.com | 100000-0002-2048-5979
}

\begin{abstract}
In this study our goal was to examine the masculinity associated to heteronormativity in a gay app from the users' point of view, which was made through an inductive study based on semistructured interviews with app users. Main results suggest that Grindr is used as a contemporary form of sociability, mainly because it provides comfort and distance from segregated spaces. At the same time, it allows discretion in sexual encounters, which only happen between "equals": white, young, athletic, handsome, and not effeminate men, and all those who differ from this profile are repelled. Heteronormativity imposes a pattern of masculinity that has overwhelmed everyone indiscriminately. Those who do not fit this profile can only be resigned to a secondary role at virtual community. Thus, technologies like this can aggravate marginalization of those already on the society fringes if forms of sociability continue to reproduce the oppression of prevailing heteronormativity.
\end{abstract}

\section{KEYWORDS}

Heteronormativity, Masculinity, Prejudice, Gay, Technologies
${ }^{1}$ Universidade Federal de Minas Gerais, Belo Horizonte, MG, Brasil 


\section{INTRODUCTION}

For a great part of the world population, the exponential growth of social media is quite noticeable, even for many researchers (Gudelunas, 2012). Although it is undoubtedly an expansion of contemporary society' ways, it does not leave behind the social inequalities, hierarchies, and disputes linked to matters of genre, race and sexuality in the real world. Thus, it is not possible to conceive of technologies outside of the social-discursive disputes and power relations that qualify some groups and disqualify others (Miskolci, 2009; Grohman, 2016).

From a series of possible paths to explore, in this study we deal with masculinity, as associated to heteronormativity on a app highly used in the gay community based on the discourses of the users. Masculinity can be understood as a cultural modality which is continuously reinforced in several organizations that bestow a range of privileges to individuals considered masculine (Andreoli, 2011), which is a highly appreciated product by both men and women (Carrieri, Diniz, Souza, \& Menezes, 2013), despite not being entirely achievable for almost no men (Almeida, 2002). Heteronormativity works as a set of practices, discourses, values, and beliefs that are lived and established as the only legitimate possibility for expressions of sexuality and genre (Warner, 1993).

Dating apps brought new perspectives for the triad of sociability, virtually, and sexuality, since that, although the hegemonies are kept, their mechanisms differ from the non-virtual ones, opening new possibilities, as the virtual world allows anonymity for the users as well as the chance to increase discriminatory speech that would not be personally said (Rotenburg \& Stroppa, 2015). Grindr is a mobile app created in 2009 and marketed to gay men; it works based on the location-based-real-time (LBRTD) logics (Blackwell, Birnholtz, \& Abbot, 2015). According to the authors, this app has around 3.6 million users in 192 countries. The platform is a simple interaction tool, from which it is possible to obtain information about the nearest users as well as their distance, photos, height, weight, to which "tribe" they belong to, and also to chat. This choice was made because Grindr was the most popular app amongst gay men and because there are no studies about heteronormativity and masculinity in this space existing in the field of Brazilian Organizational Studies.

Grindr is used for several purposes: social interaction, sex seeking, social inclusion, entertainment, dating (Van de Wiele \& Tong, 2014), and now is attracting the attention of studies about unsafe sexual behavior (Rice et al., 2012; Landovitz et al., 2012), or about social media as Blackwell, Birnholtz and Abbot (2015). Our study, which is more aligned to the one of Grohmann (2016), Miller (2015) and Licoppe, Rivière and Morel (2015) tries to go over how masculinity and heteronormativity demonstrate themselves in a virtual environment from a critical perspective.

This sex access speech is immersed in a liberal logic, and, according to Illouz (2011, p. 114), "radicalized in an extreme way the idea of "I" as selector and the idea that the romantic date should result on the best way possible", which ends up reinforcing inequalities such as asymmetry between black and white gay men, rich and poor, fat and thin, effeminate and masculine, heteronormative or not. In addition, the liberal logic has influence in the dichotomy between public and private spheres. Grindr, according to Ahlm (2017) presents characteristics from "gay villages", on which the people wear their own symbols and signs to make themselves visible among them and invisible to society.

Valenzuela (2016) points out that the liberal character from social networks has increasingly deprived the presence of gays in public spaces and privatizing their interaction in "safe and discrete" places. This "privatizing" is also noticed in the studies of Miller (2015), who identified seven 
BBR

17

116

attractive characteristics of the Grindr to its users: safety, control, facility, accessibility, mobility, connectivity and versatility that make it possible to its users to explore their sexuality without the "exposure risk" and reinforce liberal hegemonic values (Valenzuela, 2016). Among these values, we highlight on this study the masculinity and heteronormativity displayed on the users chats and how these phenomena regulate their way of interaction, socialization, communication and noticing each other. (Licoppe et al., 2015).

\section{MASCULINITIES - IN THE PLURAL}

Social networks are dispute spaces and, according to Grohmann (2016), the virtual environment of Grindr presents specific conflicts as a discursive normalization linked to senses of masculinity and femininity. The symbols related to masculinity are highly valued whereas femininity is not desired. According to Oliveira (2008), whereas the concept of masculinity is relatively recentaround the 1970s - the construction of masculinity is present since ancient Greece (Foucault, 1988) - in Brazilian organizational studies, the topic has not been much explored in a critical way, with some exceptions (Eccel, Saraiva \& Carrieri, 2015; Alcadipani, 2012; Souza, Moraes, Duarte, \& Higashi, 2012). Extensive advances have been observed in other areas of knowledge, but there is still relatively little production critically positioned in this regard within Organizational Studies, with the exception of the Gender, Work \& Organization journal.

The ideal of masculinity, on which virility and strength is emphasized, begins between centuries II and XVIII (Mosse, 1996). Since then, it has been constructed as the desirable and legitimate manner of male behavior. According to Holter (2004), the studies about masculinity can be divided into two groups: 1) theories of hierarchy and gender, and 2) theories about structural inequalities. The studies aligned to the theories of gender hierarchy turn to issues related to domination and male supremacy, whereas theories about structural inequalities highlight historic sociocultural dynamics in the discrimination and exclusion of certain groups. The two perspectives presume that masculinity refers to social constructions and that it is not influenced by for biological aspects, a perspective that this study agrees with (Souza et al., 2012).

When thinking about masculinity and its socio-historical construction, it is important to think about construction of the non-masculinity. Throughout history hegemonic masculinity was created (heterosexual, white, and Christian) and a subordinate masculinity (all the others) that presented a contrast related to race, ethnicity, sexuality, and origin (Kimmel, 1998; Connel, 1997; Lamont, 2000), with implications for the subjects, who even define their career possibilities by considering where their masculinity can be fit, as in the case of the military studied by Hale (2012). She came across a context in which masculinity is rebuilt because of militarism, which ends up producing a military masculinity, associated with the recognition of organization and compliance. Nothing is closer to the heteronormativity perspective, which distinguishes them from the subjects' adherence to the heterosexual pattern.

Sexism and homophobia are in the core of the construction and affirmation of masculinity, which is not about a static cultural product, as it is being in constant change and varies from culture to culture, from time period to time period and, even from epistemology:

Masculinity is not a property of any type of essence, neither mythical nor biological. They (1) vary from culture to culture, (2) vary in any culture along a certain period, (3) vary in any culture through a group of other variables, or potential identity places and (4) vary throughout life of any individual man (Kimmel, 1998, p. 105). 
As masculinity is a mutable cultural product, is important to discuss not masculinity per se, but masculinities in the plural, once it is possible to recognize subordinate masculinities (Lamont, 2000), and discuss both the power relations and present hegemonics. The relations of superiority and subalternity in masculinities occur because their pertinent carriers adjust themselves to heteronormativity. Thus, those who are closest to what is expected of a heterosexual will enjoy higher positions and, in the same sense, those who disagree with the expected occupy inferior positions, which ends up by hierarchizing masculinities, so that the most valued man is the more masculine, and all other manifestations of masculinity (Rumens, 2017) are distributed in positions inferior to him. As the association of the concept of masculinity is common only to heterosexual men, Souza et al. (2012) calls attention to the necessity of studies that try to understand other groups' masculinities, as the LGBT, one of the most pressed group and their relations with masculinity (Jerusanlinsk, 2005).

As far as Grindr is concerned, because it is a form of historical-social arrangement on which masculinity is valued, there is also a denial from the feminine and/or from the non-masculine (Grohman, 2016). In this sense, it is possible to think of an intersectionality between masculinity and the Grindr virtual world and its influences on the sociability of its users, what we are trying to discuss when we raise symbolic and discursive elements such as a "linguistic ideology" (Licoppe et al., 2015) and the appreciation of the masculine body (Oliveira, 2010).

The explanation of the masculinity symbols and discourses in Grindr can be supported with the studies from Eccel, Saraiva and Carrieri (2015), who claim that inside the subordinate masculinity there are gaps of power and legitimation related to effeminate men. As the studies of Licoppe et al. (2015) suggest that masculine physical appearance may, on the other hand, be also the "closing door" to the possibility of interaction. Thus, Souza e Pereira (2013, p. 99) affirm that gay men are products and producers of their own rules, that is the fact that the "homosexuals are also invested by the hegemonic power relations, also produce a discriminatory speech toward 'them' reproducing the heteronormativity, which they are victim of.

\section{HETERONORMATIVITY, ITS PERMANENCE AND ASPECTS}

Heteronormativity, as well as a masculinity, is socially constructed. In social imagery and in routine speech it is possible to notice that some gestures are considered masculine and other feminine, a well-demarcated and hierarchical binarism. According to Souza Pereira (2013), this is a heteronormative society. According to Petry and Meyer (2011), the vocabulary "norm" refers to something that regulates and seeks to make equal; added to this we have an idea of the current heterosexual norm. Santos (2007) points out that the idea of "norm" also refers to what is normal and natural. In other words, heteronormativity would be associated with natural and expected individuals. Thus, the concept of heteronormativity is encompassed by gender studies (Moura \& Medeiros, 2014), which we understand as

\footnotetext{
Organizer of culture, and that in articulation with sexuality, shapes the way how men and women should behave, how their bodies should be represented and how their interpersonal relations can be composed, in these fields (Petry \& Meyer, 2011, p. 195)
}

Heteronormativity, being a group of "rules", is (re)created through discourse, practices, beliefs and costumes, directly influencing people sociability. According to Warner (1993), several times this standard way is seen as the only valid one to express sexuality. The belief that there are two complementary sexes, and, of correspondence, nearly automatically considered, among genres 
and sexuality in a binary way (Butler, 1993), contributes to the (re)production and appreciation of heteronormativity from small social interactions to the large ones. There are, in society, however, even micro physically (Foucault, 1979), ways to standardize and rank the behavior of the individuals, especially sexual:

heteronormativity aims to regulate and standardize ways to be and to have the desired body according to what is socially established to people, in a deterministic and biologist way, there are two - and only two - possibilities of people leasing human sexual anatomy, there is feminine/ female or masculine/male (Petry \& Meyer, 2011, p. 193).

Considering these microphysical mechanisms of standardization and ranking in the organizations, many are studies that investigate heteronormativity in the organizations (Eccel, Saraiva \& Carrieri, 2015; Garcia \& Souza 2010; Ferreira \& Siqueira, 2007), being necessary to highlight as well, the surveillance in the social networks explored by Louro (2000): negative speech, swearing, isolation and even blocking and virtual bullying. The control is not done only by the external ambience, but also by the individual that learns how to examine and govern himself.

If, in Louro (2000, p. 60), "the body seems to have been out of school", the situation seems to have become more acute with social networks, since subjects and their bodies, strictly speaking, have their presence there are justified by their sexuality, in the case of Grindr. It is not a question of any sexuality, but of something properly framed in "acceptable", heteronormative, appropriate, parameters in a dynamic context, in which modes of cooperation are produced socially (Mizocsky, 2010). This notion of organization allows Grindr to be taken on from an organizational point of view, since it revolves around the sexual interests, a series of efforts, from the programmers and sponsors to the members, who register, interact in search of sex, but the "right" kind of sex, reproducing heterosexual patterns.

The normativeness and surveillance cause the "stress of minority" that, according to Souza and Pereira (2013) and Petry and Meyer (2011), is a state of psychological stress that stigmatized groups can develop. Symptoms include anxiety, neurosis, a feeling of internalized homophobia, which has a strong influence on the individuals, as Eccel, Saraiva and Carrieri (2015) and Miller (2015) highlight. Grohmann (2016) points that at Grindr, influenced by the "epistemology of the wardrobe" many bisexual and gay men adopt heteronormative patterns as a way of hiding their sexuality. In the words of Carvalho (2012) it would be a "misogynist heteronormativity", if it was used in order to be closer to the masculine behaviour and distant from the "feminine" ones - which, on social networks, ends up hierarchically in "successful" and "unsuccesful" profiles.

\section{METHODOLOGY}

From the inductive method, the starting point of this research was the questioning of masculinity associated to heteronormativity on a gay app from the speech of its users. We developed qualitative research, since it allows more freedom to lead the research in a more relevant way to the object and context one wishes to study (Denzin \& Lincoln, 1994). The operation of the research was done through interviews, using a semi-structures script. We observed the indications of Kozinets $(1997 ; 2002 ; 2015)$ to deliver the interviews such as: (1) a place of intense traffic of message exchanging, rich in descriptions, such as the way the app was used in different points of the Belo Horizonte Metropolitan Region (MBRBH); and (2) conducting interviews through direct interactions with users via chat. 
The interviews were done with 32 users from different parts of the MRBH, who will not be identified, because what interests us was the content. The Grindr profile used for the interviews had a brief description of the study and highlighted our role as researchers, as the interviewers were aware of the aim, following the steps of Braz (2010).

The collection by chat was interesting because of its methodological possibilities, but we had in mind the virtuality of relations which possibly would be extended to research. In an application where there is no control over the users' profile, with only one email account being required for the registrant, it is plausible to expect fictitious profiles, with information and photographs that do not belong to them. As for the demographic profile, although we know of the significant differences among the various tribes of the LGBT population, this information was not relevant not only because we could not verify it, but also because of the anomic issue. Our data production strategy, therefore, focused on the content of the testimonies, material systematically worked on with a discourse analysis, which allowed its validation.

Regarding the production of field data, two things need to be said: First, the challenge of making the interviews. Besides the presence issues, it was quite challenging making connections through an app chat, not only for a matter of purpose, as many were looking for sexual meetings, but also for the short phrases and interactions, associated with the difficulty finding and keeping a dialogue with the interviewees, which made the analysis harder, as will be shown further. The second surprising point was the harassment. We do not know if the "researcher" profile brought up some kind of fetish, but in several situations, we were harassed, making it difficult at first to separate the genuine information and the ones who were apparently only interested by "researcher profile". However, we managed to solve that when we interacted with the users. The material produced in the field though, was submitted to a systematic treatment, which allowed us to filter what we have obtained.

In order to analyze the interviews, we used the structuralism analysis of the discourse. This perspective, supported by linguistics, takes into account the social production context of the speech. From the structuralism epistemology of the 1960s, this approach enables us to make an "internal analysis (what does this text say? How does it say?) and an external one (why does this text say what it says?)”, relating language and society (Gregolin, 1995). As language is a product of ideology, it brings representations of class into society. Speech like this is full of ideology and located in social terms. The speaker does it from a specific place in the social plan, where it shows its ideologies through its speech. Being necessary to investigate the discursive strategies of the ideological persuasion used by the people so that we can understand what they actually say. Identification and analysis were done in ways: a) lexical (analysis of a vocabulary used in a discursive formulation), and b) the sematic way done from themes and figures. It "[...] corresponds to a recurrence, along the discourse, from subjacent and semantic elements" (Faria, 1998 p. 142). He adds up saying, "[...] the semantic pathway notion encompasses the concepts of Greimas of thematic and figurative pathways, corresponding to the recurrence of semantic pathways more abstract or more concrete, respectively" (Faria, 1998, p.150); c) from interdiscursive aspects. According to Mainguenau (1998, p. 86), “[...] an interdiscourse can be called a group of discourses. [...] If we consider a particular discourse, we could also call interdiscourse the group of discourse units, which it has a relation with. Fiorin (1999, p. 231) adds "[...] the identity of a discourse depends on its relation with others, that is, it does not constitute independently to other discourses, to, after that, relate with them, but it constructs itself on a frugal way, inside this opposition, defining on the limits of this polemic relation; d) from aspects of discursive syntax. 
BBR

17

120

The discursive syntax refers to the structure on which each discourse is constructed. It includes figures of speech such as metaphors, metonymy and hyperbole; e) aspects reflected and refracted in discourse. Linguistic refraction is a discursive strategy analyzed by Bakhtin (2006), which goes from redefines the discursive issues. Every aspect is, at the same time, linguistically reflected, preserving its socially established sense and, refracted as reinterpreted according to the referential and speakers. Thus, a speech reproduces (or reflects) the social conditions on which is produced, and modifies (or refracts) specific aspects, according to the redefinitions of the speakers; f) from the social conditions of the discourse production. Besides the context of discursive conversation, it refers to the real conditions on which the speaker had to speak that way and not another way. In other words, it is identified here which social elements the discourse is produced; g) from the discourses presented in the text. They are understood as social production of the text; $h$ ) from the ideological aspects defended on these discourses; i) from the ideological aspects fought on these discourses. In discursive ways, ideology refers to the intention of the text, that is, the immanent position of a certain speech. As there is no neutral discourse, it presents a defended position. Same way, it takes a position about the fight in ideological terms; and j) from the position of the text as related to hegemonic speech in society. Here, it is compared the position defended on the discourse with the hegemony discursive in society, can be identified, whether the discourse is aligned to what is dominant in social terms, or something marginalized is constituted.

\section{ANALYZING AND DISCUSSING THE RESULTS}

In Brazil, the discussion about the LGBT population is recent and complex. In addition to the peripheral question, the complexity is due, in part, to the criticisms already known about the fragility of the political identity characteristics of the acronym, which would constitute a heap of letters without a common agenda between the groups (Sierra \& César, 2014). The movement reveals hegemony of middle-class gay white men to the detriment of other groups, which creates tensions of various kinds. The country has continental dimensions, varying enormously the way in which each of these groups presents itself in each of them. Despite the positive impression of the LGBT Pride parade in São Paulo, the largest in the world with more than two million participants, the LGBT faces the challenges posed by a conservative government, which among its first Measures published provisional measure 870 which excludes this population from policies and guidelines aimed at the promotion of human rights, as well as defining the assignment of a directorate under the National Secretariat for Global Protection to the promotion of LGBT rights, a regression (Queiroga, 2019). A disturbing measure. The fact is that Brazil is actually the most dangerous country for this population, with the highest number of murders, which demands specific public security policies (Mello, Avelar, \& Brito, 2014).

The data that was produced allowed us to arrive at five discursive categories, all of them related to masculinity, and heteronormativity in a gay app. They are 1) the use of the app; 2) confidentiality; 3) self-image; 4) profiles of rejection; and 5) girly profiles; and their analysis will be as follows.

\subsection{UsES OF THE ApP}

Related to the use of app, it is interesting to emphasize several possibilities of its use, based on the user's testimonials. Among them, the possibility to obtain fast sex, which is supported by Van de Wiele and Tong's (2014) ideas. To them, the users of the app have many different reasons to be there, specially the possibility of fast, non-commitment sexual relations. Grindr 
is especially attractive as it allows safety and the fact that one does not need to leave home, as Miller (2015) stated.

(1) Before I didn't like using it. I started to use after my friends, but then I noticed how good it is. What I like better is how easy it is to access people. You can chat to people near or far from you besides being possible to control whom you talk to. The guys I find boring I block and that's it. I also like to use it when I go to new places, that way I am able to meet different people. (E24).

(2) Nowadays is much easier to have meetings and friendship through the internet, those apps help a lot. The most interesting is the fact that you can use at home, is safe. I don't go to gay ambiences. (E11)

Some features such as convenience, control, mobility and connectivity are emphasized on these talks. The app allows a position of choice to its users, whose decisions can be done immediately, confirming Miller (2015). Another issue that came was that Grindr represents a specific space to know, interact and meet new people, as well as the studies developed by Illouz (2011), Licoppe et al. (2015), and Grohmann (2016). The excerpts suggest that the app allows to its users not only possibilities of choice on their interactions, but also more comfort.

(3) I use the app because it is a very practical way to know gay guys. I cannot always go to nightclubs and pubs to get to know them, and on the app you have many options, many different profiles, I do not use it for serious relationship, because the purpose of the app is flirting, and from my experience I noticed that the other profiles are not interested on serious dating.

(4) At the app I can meet people without getting out of my house, it is very easy. I do not need to go to gay places; I don't even like those places. Since I downloaded the app, I find it much easier to know someone for a casual dating.

Excerpts (02), (03) and (04) show the possibility of emptiness in public places due to the comfort and convenience of the virtual world (Ahlm, 2017; Valenzuela, 2016). The users see on it a way to interact without exposing themselves and from their homes. There are elements of convenience, as the app shows possibilities to the user wherever they are, as well as protection. Brazil is the country where the LGBT population is killed in world's highest number, so staying home can be safe - even if this implies privacy and confidentiality - and with that, a step back.

\subsection{Confidentiality}

These second category, "confidentiality", is based on one of the most common lexicon in interviews, together with "in the silence", "confidential”, "discreet", "never mind", supporting Rottenburg and Stroppa (2015), according to which a strong attraction of the virtual world is the possibility of anonymity. On Grindr, where most users are closeted gay men, anonymity and confidentiality are desirable.

(5) I only chat with s confidential profiles. nowadays the "faggots" speak very loud and I haven't assumed my homosexuality yet. I need to feel that the person is in the same mood as me, that is why I'm into sending pictures. (E14)

(6) I am from the countryside, so in BH silence is essential. Even boring. Nevertheless, I understand who asks for privacy.... Because when I go to the countryside, I am as private as possible. (E17) 
BBR

17

122
(7) It is not necessary to show everything that is done, neither to become paranoiac with it. But I understand the need of confidentiality, nobody wants to be gossiped about. (E28)

On the opposite way of confidentiality, some people are not interested in privacy:

(8) The person hides himself because is wrong? Because they are married, "curious straight" or because they are betraying a serious relationship? I don't think confidentiality is a healthy thing, because I don't think using an app or being gay is a problem. I don't believe it is essential because the stigma will continue, as well as the exclusions therefore I avoid these kinds of profiles, on top of that, many time they ask for privacy because either they date or are married (to women and have kids) (E30)

In general, the interviewed have a common point regarded confidentiality, it must be respected, and according to the words, "I understand who asks for confidentiality". Considering the same context from the majority, which can result into casual sex, confidentiality is a nice attitude that can result in dating and a good image among users. Although is not a consensus, confidentiality is fundamental when exchanging messages and arranging possible encounters:

(9) Grindr is a den of depravation; there are many guys here who are married to women, full of closeted gays. That is why privacy is so important to them. (E16)

(10) I think confidentiality is quite important, in my case, my wife has no clue that I go out to fuck some fags. Because I am not gay, I only like to fuck their asses. Because of this, I say immediately, if you want to be fucked, it must be confidential. Who fucks in silence, it will always fuck. (E16)

(11) Confidentiality is a personal thing, if one does not feel comfortable in exposing himself for any reason; he has the right to keep private. It is not essential, but each one has the right to keep his privacy. (E16)

(12) Not everyone asks for confidentiality. Normally only the ones who have not assumed their homosexuality yet or date. I guess we have to respect, don't we? Everyone there, we afraid to assume one day. Many issues are involved: family, friends and even personal issues. I do not ask for confidentiality, but I have asked one day, today, I respect. (E18)

Another dimension for "confidentiality" is the fact that are discourses related to the masculinity one: it is necessary to protect the privacy of the man who has sexual intercourse with gays. It is also important to highlight "I am not gay, I only like to fuck some fags" (010), that shows the reflection and linguistics refraction. The reflection is on the fact that girly homosexual is inferior when compared to heterosexual; the refraction when the speaker hides his own homosexuality stigmatizing the gays who he has sex with in order to have a self-image that suggests being superior.

\subsection{Self-IMAGe}

Self-image is the third category. Aspects related to self-image and physical appearance was highly visible on the interviews. The users are always worried, reaffirming features that are valued on this virtual world.

(13) People should be more authentic on these apps, posting pictures of who they really are. There are fat guys who take pictures laying down just to appear thinner. There are girly guys who talk full of awful slangs just to appear masculine, and when they arrive they put their hair from one 
side to the other, walk like a lady. It is complicated. I care a lot have a nice body. I am handsome, discreet... That is why I seek for similar. (E2)

(14) Dude, Grindr is cool, but there are some weird people. However, they do not understand that each one likes something different. I will not go out with a fat guy because I go to the gym regularly. It is nonsense for me. At my profile it is clear what kind of guys interest me (E16)

The self-image speech presents the semantics way of beauty ("thin", "masculine", "handsome", "nice body"), masculinity ("discreet") and heteronormativity ("authentic"), serving as a basis to reject the "others" because they don't fit in the ideal of heteronormativity for being "fat", "girly", "weird guys". There is a crossing speech opposing the "acceptable" and "unacceptable" at Grindr. As Grohmann claims (2016), the athletic bodies are associated to the lexicon referred to taking care of oneself ("I care a lot") on a body and image issue.

(15) I am not into guys who are overweight and use woman's hair, but I respect. (E9)

(16) I am okay with it, but I am not into feminine gays, crossdresser. I like man, you know. Moreover, those crazy ones come, with a star tattooed on their shoulders and they say are male. (E11)

(E17) There are people who do not respect what I like. I do not discriminate the girly ones or anything like that. I just do not like to be with them. (E12)

(18) Here (referring to the app) is a men place, I do not know what these girly fags are doing here. They say they are male but when we see them, it is worse than a lady, I feel angry about it. (E32)

Still regarding self-image speech, the excerpts (15), (16) and (18) show that the speakers prefer others that fit the rules and reject the ones that don't. The ranking and idea of "I am not/ I don't like" are visible on the app, as though it is a matter of preference and not violence. Notice the vocabulary of violence when they claim "overweight guys", "that use woman's hair", "female gays", "crossdressers", "crazy", "worse than a lady", in a manner that is extremely prejudiced and degrading. This speech can be seen as a form of legitimation between acceptable bodies and the ones that are rejected into a hegemonic pattern of beauty. According to Grohmann (2016) there is a social construction of the preferences at Grindr, putting some as legitimate and others not, discursively modifying the successful people at the app - that is, making distinctions and reproducing power relations that are seen in society. Moreover, we emphasize the semantic pathways of preference of the social condition from production of the discourses about aesthetics: the fact is that being gay is taken as wrong, and anything that develops homosexuality is repulsive and must disappear.

There is yet another significant element: an explicit misogyny, since effeminate gays are not just discriminated against because they do not match the male ideal: they are because they are inferior, as women would be. In speech, everything that refers stereotypically to the masculine is reified in the same proportion in which there occurs debasement of everything that refers to the feminine stereotyped form. Therefore, presenting any kind of feature that associates gay man with a woman automatically lowers him because he approaches the feminine, which is despised. Marilyn Frye (1983) provides a clue in this regard. She maintains that heterosexual men reserve to other men aspects such as admiration, recognition and respect, restricting their relationship with women, considered inferior, only to sexuality. That is why they are treated in a gentle and paternal way, to the extent that they are disregarded as interlocutors on an equal footing. It is not difficult to assume that, among gays, the logic holds, but in a complex way: women are 
BBR

17

124

not hated, since there is an affective proximity of many of them; however, what lowers gays is appearing similar to them in some way. They continue, thus, to represent something inferior, despised by gays.

\subsection{Repulsive Profile}

The fourth category is repulsive. As Grohmann says (201), we identify that there is a due denying game from the "other" as a way of hierarchy:

(19) What attracts me the least is guys with make-up, or wearing female clothes or much older than me. (E3)

(20) I do not like and do not talk with bottom, twinkie gays, who like quirky stuff (sexually speaking), or show incompatible ideas to mine. (E8)

(21) I do not like short men. I don't know, it seems like it doesn't fit. I want a bear. (E20)

(22) I don't like bottom gays. Though, worse than being bottom or twinkie is to smoke. No one can stand that smell. I block immediately. (E27)

(23) I don't like Twinkies and shirt dick guys lol. It is a deception, worse still when they are a fag, twinkie, queer and a tiny dick, I block. (E29)

The semantic pathway of graduation is signed by several lexical selections that explain what is inferior and, therefore, rejected: age, sexual preferences, incompatible ideas, height, defined sexual roles, penis size and, mainly, being feminine (Moura, Nascimento, \& Barros, 2017). Rejection, although is presented as a "taste" issue, transforming into targets all those "different" from what heteronormativity determines. The excerpts make clear the prejudice shown to those who are different from the "bear" profile. Even ideas can be enough to reject someone, which reinforces the idea of not being capable to deal with the other. As in Eccel, Saraiva and Carrieri (2015), one can notice prejudice among those who are discriminated for being as they are, which can be extended to a virtualized sociability:

(24) I wouldn't say that I have prejudice with twinkies or fat gays. I'd rather not to have a relation with them, but I am open to friendship. It is just a matter of taste, there is nothing to do with prejudiuce or judgment.

(25) I respect everyone who is at Grindr, but I don't want to have a relation with all of them, do you understand? Having prejudice is different from respecting the profiles that do not interest me. $(\mathrm{E} 10)$

(26) The normal profiles are more attractive to me. But I respect them all. (E1)

The excerpts (24), (25), and (26), show that rejection is, once again, preferably requalified. Nevertheless, the discursive syntax shows that the use of the conjunction "but", expresses the idea of contrast, and undoubtedly the idea of prejudice, although it is never assumed, instead it is denied that this is a bias towards non-hegemonic profiles, which reproduce the discrimination that gays themselves suffer in society. During the interviews, critical profiles and ones out of the pattern ones were found. Even though being a minority, some users subvert the hegemonic order of beauty, masculinity and even the way of socializing commonly on the app. 
(27) I have little patience with profiles full of sexism, intolerance, prejudice. I confess that terrible environment, you know. (E30)

(28) There are some users who don't understand that the app is to be used by the general LGBT community and not only a specific public. It seems that one will only have a space if you go to the gym and are in shape. Oh no, I am there, no matter what. Occasionally I find a gay with a more good (sic) head. (E32)

Excerpts (27) and (28) show explicit discrimination at Grindr. Words such as "sexism", "intolerance", "'prejudice", and "horrible environment" were used to show the bigotry inside the community of the app. It is curious to notice a specific prejudice that came up, the linguistic one, referring to the ones who do not express themselves correctly. This type of prejudice also contributes to the "horrible environment" that was criticized, on which it is possible to distinguish the "successful profiles" and "profiles with less access", among which the Twinkie ones are the main aim of prejudice.

\subsection{Girly Profiles}

As it has been discussed, Grindr shows specific collisions as discursive standardization linked to a high value of masculinity and a low one to femininity (Grohmann, 2016)

(29) You find everything here. Some are so gays, others are okay. Nevertheless, I suppose the guys who are masculine are more successful, because they are more handsome, right? It is harder and harder to find them because the majority is girlish. (E15)

(30) I am extremely discouraged about grindr, because we can only find here faggots. Real man is missing. The majority of times I am online I don't find anyone, because no one attracts me. (E17)

(31) Surely the "bear" guys are much most wanted, many people had given up going out with me because I am effeminate and I say it. Sometimes I even say "yes, I am girlish and so are you, the only difference is that I have the guts to tell it", just to provoke them. (E19)

From the vision of the users, the effeminate profiles are considered less attractive (words such as "very gay", "lady", "faggot", "girlish"). Masculinity, a series of privileges for the ideal of "male", besides being unreachable, serves as a parameter to oppress all, even knowing that Grindr is an app for the gay community writ large.

(32) The majority pretends to be what they aren't. Many times the guy says he is male only with his mouth closed (LOL). It is boring you meet someone and that happens.

(33) Majority of people show themselves as masculine, "bears". Actually are not. Most try to hide they are feminine, because few people like this. I choose very carefully the picture to send, because depending on the picture, the person blocks you. (E26)

(34) I see all kinds of people here. But I guess the trend is to say that neither you are, nor enjoy girlish profiles, even if deep inside you like it. My view is that, we live in a sexist and homophobic society, so the more masculine you are the better. (E30) 
BBR

17

126

When we talk about the "necessity", of "pretending to be what you are not", "close the mouth", "hide being feminine", it is noticeable that the dominant ideology, in the majority of the users, supports the hegemonic discourse of masculinity/heteronormativity in society. And the other face of this same discourse is misogyny, which automatically condemns someone placed to an inferior position by resembling a woman. Likewise, Connel (1997) claims masculinity was forged in contrast to non-masculinity; it is possible to think heteronormativity and non-heteronormativity. His words are clear when it comes to body shape (Louro, 2000), which includes self-exam and self-control to seek for acceptance in any context.

(35) Hanging out with dirty people is hell because you become just like them. That is why I don't even talk with these profiles. I want to keep being male. (E4)

(36) I'd rather not hang out with faggots, because I am not one. I take care, you know. I don't get camp. I even prefer to be confidential, that why I do not expose myself.

(37) I avoid gay vocabulary. Gee, the girlish ones have many nonsense slangs. When they call me those words, I do not even respond. I hate when they call me sister, girlfriend, that kind of thing.... (E26)

The excerpts (35), (36) and (37) show visibility and sociability themes. Any kind of socialization with effeminate gays is avoided. The movement is somehow "studied" because it is as though the proximity with the different ones were sufficient to hide the masculinity. It is amazingly contradictory the excerpt "I want to keep being male". The speaker suggests a fragile masculinity, easily questionable if he began hanging out with effeminates, which is what protects himself to assume his prejudice. Finally, we have found speech that refer to the idea of minority stress (Souza \& Pereira, 2013; Petry \& Meyer, 2011), a psychological state that stigmatized groups can develop.

(38) To tell you the truth, I am ashamed about being on this app until today. A 30-year-old-guy, it is definitely not what I dreamed for my life. However, you know how difficult it is for men to go without sex; I am here only because of it. Nevertheless, I am going to delete it, soon. (E2)

(39) Frequently after a date, I feel bad. I get sad, guilty. It is weird. (E15)

(40) Sometimes, it seems like I am doing something wrong. I feel bad, I feel like deleting the app. (E26)

The words "ashamed", "feel bad" and "something wrong", clearly show discomfort. The excerpts point out that just having the app, as in (38) is disappointing, possibly because of some dream of the speaker about how would it be to be 30 , and in a stable relationship, as the heteronormativity claims. This excerpt is also important to reveal that, because it is so difficult to men to live without sex they look for Grindr. This is a linguistic refraction, as the absence of sex impacts any human being (reflection). Transforming this aspect into something exclusively masculine ends up justifying the discomfort in in being a man, for needing sex and therefore, purifying the women. 


\section{FINAL CONSIDERATIONS}

In the study we aimed at examining masculinity as associated with heteronormativity on a gay app though speech of its own users, which was done via an inductive study based on semistructured interviews with men who use the app. The main results suggest that Grindr is used as a way of sociability, especially because it provides comfort and the possibility to stay away from segregated spaces. Also, it offers confidentiality on sexual encounters, which will happen only if one can find a "similar": white men, young, athletic, good-looking and not effeminate, rejecting the ones who do not fit on the heteronormativity, such as older, black, short, fat, with long hair, and, mainly, the effeminate ones.

Our findings deserve a note that enables analytical transpositions and contributions to the Organizational Studies. It is necessary to highlight the sociability matter. Checking the data, the virtuality did not imply any change on the social patterns; instead, they not only but also increased, considering that the non-personal contact provides for new methods of violence due to anonymity. The promise that technology would bring redemption to some marginalized groups failed, once the sociability patterns kept as they used to be. Confirming the conclusions of Eccel, Saraiva and Carrieri (2015), we came across ambiguous masculinities, which reproduce the same pattern that punishes people for being who they are. It is already complex to think about a discriminated discriminating other, one that becomes even more serious with the interviewers, who despise the gays whom do not fit in the standards of heteronormativity, walking away from them. We've found masculinities - in the plural - among the users of the application. However, they seem to revolve in two axes: the masculinities of superior social status (Lamont, 2000), close to that defined by heteronormativity: athletic men, of medium height to tall, white, with short hair, and masculine appearance, and masculinities (Lamont, 2000), all of which have inferior aspects, such as men who are fat, short, black, with large, effeminate hair. It is not a question of two pure profiles, but of representations that suggest an ideal of masculine used as form of hierarchy of users of the application.

And this brings up another question: misogyny. Being effeminate, somehow resembling a woman in appearance, tone of voice, language or behavior automatically lessens the gay. The heterosexual norm is thus compulsory, dictating who will be "successful" in the applications: those who, besides being male, seem more to be "male", "discrete", "brothers" (Misckolci, 2009), which correspond to the current heteronormativity. For gay men who cannot or do not want to respond to the male ideal, they are aligned to a marginal position within the marginal experience of non-heterosexual sexuality, a possible source of tension and suffering.

It is more important to appear male at any cost than to live their own sexuality in a healthy way. Even though the app is for the whole community, it is noticed the supremacy of a specific group that judges and rank all the others according their appearance, voice, malesness, being sexually active, being white, good-looking, tall, thin, athletic, and discreet, the others can only have a secondary role, and be submissive.

That explains somehow why part of the interviewed enjoy not having to go out from home looking for dates. Besides the danger of being gay in Brazil, the virtual frustration may be less difficult to deal with, nevertheless frustrating as well. That would make the apps, such as Grindr, a "safe" place to be, a "modern pub" (Miller, 2015), where being invisible and anonymous is for everyone, being more difficult to build emotional ties, high self-esteem, and life in society. Thus, technology can become a device of roughness and the worsening of the marginalization 
BBR

17

128

of whoever find themselves at the edge of society if the sociability keep reproducing the bullying of heteronormativity. We should all reflect about this.

\section{REFERENCES}

Ahlm, J. (2017). Respectable promiscuity: digital cruising in an era of queer liberalism. Sexualities, 20(3), 364-379.

Alcadipani, R. (2012). (Re)descobrindo as masculinidades. In M. E. Freitas \& M. Dantas (Eds.), Diversidade sexual e trabalho (pp. 51-78). São Paulo: Cemgage Learning.

Almeida, M. V. (2002). Senhores de si: uma interpretação antropológica da masculinidade. Lisboa: Fim de Século.

Andreoli, G. S. (2011). Representações de masculinidade na dança contemporânea. Revista Movimento, 17(1), 159-175.

Bakhtin, M. V. (2006). Marxismo e filosofia da linguagem (8th ed.). São Paulo: HUCITEC.

Blackwell, C., Birnholtz, J., \& Abbott, C. (2015). Seeing and being seen: co-situation and impression formation using Grindr, a location-aware gay dating app. New Media \& Society, 17(7), 1117-1136.

Braz, C. A. (2010). À meia-luz - uma etnografia imprópria em clubes de sexo masculinos (Doctoral Thesis). Instituto de Filosofia e Ciências Humanas, Universidade Estadual de Campinas, Campinas, Brasil.

Butler, J. (1993). Gender trouble: feminism and the subversion of identity (2nd ed.). New York: Routledge.

Carrieri, A. P., Diniz, A. P. R., Souza, E. M., \& Menezes, R. S. S. (2013). Gender and work: representations of femininities and masculinities in the view of women Brazilian executivies. Brazilian Administration Review, 10(3), 281-303.

Carrieri, A. P., Perdigão, D. A., \& Aguiar, A. R. C. (2014). A gestão ordinária dos pequenos negócios: outro olhar sobre a gestão em estudos organizacionais. Revista de Administração, $49(4), 698-713$.

Carvalho, C. A. (2012). Jornalismo, homofobia e relaçôes de gênero. Curitiba: Appris.

Connel, R. W. (1997). La organización social de la masculinidad. In T. Valdez \& J. Olavarría (Eds.), Masculinidadles: poder y crisis (pp. 31-48). Santiago: Ediciones de las Mujeres.

Denzin, N. K. \& Lincoln, Y. S. (Orgs.) (1994). Handbook of qualitative research. Thousand Oaks: Sage.

Eccel, C. S., Saraiva, L. A. S., \& Carrieri, A. (2015). Masculinidade, autoimagem e preconceito em representaçóes sociais de homossexuais. Revista Pensamento Contemporâneo em Administração, $9(1), 1-15$.

Faria, A. A. M. (1998). Discurso e leitura, semântica e argumentação em Germinal. In I. L. Machado, A. R. Cruz, \& D. Lysardo-Dias (Eds.), Teorias e práticas discursivas: estudos em análise do discurso (pp. 141-151). Belo Horizonte: UFMG/FALE/NAD/Carol Borges.

Ferreira, R. C., \& Siqueira, M. V. S. (2007). O gay no ambiente de trabalho: análise dos efeitos de ser gay nas organizações contemporâneas. Anais do Encontro Anual da Associação Nacional de Pós-Graduação e Pesquisa em Administração, Rio de Janeiro, RJ, Brasil, XXXI. 
Fiorin, J. L. (1999). Semântica e análise do discurso. In H. Mari, S. Pires, A. R. Cruz, \& I. L. Machado (Eds.), Fundamentos e dimensóes da análise do discurso (pp. 225-238). Belo Horizonte: Carol Borges.

Foucault, M. (1979). Microfísica do poder. Rio de Janeiro: Graal.

Foucault, M. (1988). História da sexualidade I: a vontade de saber. Rio de Janeiro: Graal.

Frye, M. (1983). The politics of reality: essays in feminist theory. New York: Ten Speed.

Garcia, A., \& Souza, E. M. (2010). Sexualidade e trabalho: estudo sobre a discriminação de homossexuais masculinos no setor bancário. Revista de Administração Pública, 44(6), 1353-1377.

Gregolin, M. R. V. (1995). A análise do discurso: conceitos e aplicaçôes. Alfa, 39, 13-21.

Grohmann, R. (2016). Não sou/não curto: sentidos midiatizados de masculinidade, feminilidade e classe social nos discursos de apresentação do aplicativo Grindr. Sessóes do Imaginário, 21(35), $1-11$.

Gudelunas, D. (2012). There's an app for that: the uses and gratifications of online social networks for gay men. Sexuality \& Culture, 16(4), 347-365.

Hale, H. C. (2012). The role of practice in the development of military masculinities. Gender, Work \& Organization, 19(6), 699-722.

Holter, O. G. (2004). Social theories for researching men and masculinities: direct gender hierarchy and structural inequality. In M. S. Kmmel, J. Hearn, \& R. W. Connell (Eds.), Handbook of studies on men \& masculinities (pp. 15-34). California: Sage.

Illouz, E. (2011). O amor nos tempos do capitalismo. Rio de Janeiro: Zahar.

Jerusalinsky, A. (2005). Qual o sexo de Oscar Wilde? In Associação Psicanalítica de Porto Alegre, Masculinidade em crise (pp. 15-29). Porto Alegre: APPOA.

Kimmel, M. A. (1998). Produção simultânea de masculinidades hegemônicas e subalternas. Horizontes Antropológicos, 4(9), 103-118.

Knights, D. (2019). Gender still at work: Interrogating identity in discourses and practices of masculinity. Gender, Work \& Organization, 26(1), 18-30.

Kozinets, R. (2015). Management netnography: axiological and methodological developments in online cultural business research. In C. Cassel, A. Cunliffe, \& G. Grandy (Eds.), The Sage handbook of qualitative business and management research methods. London: Sage.

Kozinets, R. V. (2002). The field behind the screen: using netnography for marketing research in online communities. Journal of Marketing Research, 39(1), 61-72.

Kozinets, R. V. (1997). On netnography: initial reflections on consumer research investigation of cyberculture. Advances in Consumer Research, 25, 366-371.

Lamont, M. (2000). The dignity of working men: morality and the boundaries of race, class, and immigration. Cambridge: Harvard University Press.

Landovitz, R. J., Tseng, C. H., Weissman, M., Haymer, M., Mendenhall, B., Rogers, K., \& Shoptaw, S. (2012). Epidemiology, sexual risk behavior, anda HIV prevetion practices of men who have sex with men using Grindr in Los Angeles, California. Journal of Urban Health, 90(4), 729-739.

Licoppe, C., Rivière C. A., \& Morel, J. (2015). Grindr casual hook-ups as interactional achievements. New Media \& Society, 18(11), 1-19.

Louro, G. L. (2000). Corpo, escola e identidade. Educação \& Realidade, 25(2), 59-75.

Maingueneau, D. (1998). Termos-chave da análise do discurso. Belo Horizonte: UFMG. 
BBR

17

130

Mello, L., Avelar, R. B., \& Brito, W. (2014). Políticas públicas de segurança para a população LGBT no Brasil. Estudos Feministas, 22(1), 297-320.

Miller, B. (2015). "They're the modern-day gay bar": exploring the uses and gratifications of social networks for men who have sex with men. Computers in Human Behavior, 51(A), 476-482.

Miskolci, R. (2009). O armário ampliado: notas sobre sociabilidade homoerótica na era da Internet. Gênero, 9(2), 171-190.

Misoczky, M. C. (2010). Das práticas não gerenciais de organizar à organização da práxis para a libertação. In M. C. Misoczky, R. K Flores, \& J. Moraes (Eds.), Organização e praxis libertadora (pp. 13-56). Porto Alegre: DaCasa.

Mosse, G. (1996). The image of man: the creation of modern masculinity. Oxford: Oxford University Press.

Moura, R. F., \& Medeiros, C. R. O. (2014). Desafiando a heteronormatividade: interpretaçóes sobre manifestaçóes das organizações a favor da diversidade sexual. Anais dos Seminários em Administração FEA/USP, São Paulo, SP, Brasil, XVII.

Moura, R. G., Nascimento, R. P., \& Barros, D. F. (2017). O problema não é ser gay, é ser efeminado: o gay efeminado e as organizaçóes. Farol - Revista de Estudos Organizacionais e Sociedade, 4(11), 1478-1541.

Oliveira. A. M. D. C. M. (2008). Masculinidade e pós-modernidade: a imagem do homem e o fim das grandes narrativas. In M. I. Ghilardi-Lucena, \& F. Oliveira (Orgs.), Representaçóes do masculino: midia, literatura e sociedade (pp. 290-314). Campinas: Alínea.

Oliveira, J. H. (2010). O corpo como significado ou o significado do corpo: poder, violência e masculinidade na polícia militar. Revista Vivência, 35, 101-117.

Petry, A. R., \& Meyer, D. E. E. (2011). Transexualidade e hetronormatividade: algumas questóes para a pesquisa. Textos e Contextos, 10(1), 193-198.

Queiroga, L. (2019). Medida Provisória assinada por Bolsonaro não explicita diretrizes para população LGBTI. O Globo.

Rice, E., Holloway, I. W., Winetrobe, H., Rhoades, H., Barman-Adhikari, A., Gibbs, J., \& Dunlap, S. (2012). Sex risk among young men who have sex with men who use Grindr, a smartphone geosocial networking application. Journal of AIDS and Clinical Research, S4, 1-8.

Rothenburg, W. C., \& Stroppa, T. (2016). Liberdade de expressão e discurso de ódio: o conflito discursivo nas redes soiais. Anais do Encontro Nacional de Direito e Contemporaneidade, Santa Maria, RS, Brasil, 3.

Rumens, N. (2017). Postfeminism, men, masculinities and work: a research agenda for gender and organization studies scholars. Gender, Work \& Organization, 24(3), 245-259.

Santos, L. H. S. (2007). Heteronormatividade e Educação. In: Anais do Seminário de Gênero e Sexualidade na Escola, Brasília, DF, Brasil, I.

Saraiva, L. A. S. (2009). Mercantilizaçâo da cultura e dinâmica simbólica local: a indústria cultural em Itabira, Minas Gerais. Tese de doutorado, Faculdade de Ciências Econômicas, Universidade Federal de Minas Gerais, Belo Horizonte, Brasil.

Sierra, J. C., \& César, M. R. A. (2014). Governamentalidade neoliberal e o desafio de uma étical estética pós-identitária LGBT na educação. Educar em Revista, n.esp.1, 35-51. 
Souza, E. M., Moraes, M. W. P. S., Duarte, P. P. P., \& Higashi, R. (2012). A produçáo científica sobre masculinidade na administração: análise dos trabalhos publicados no decênio 2001-2010. Gestão e Sociedade, 6(14), 199-218.

Souza, E. M., \& Pereira, S. J. N. (2013). (Re)produção do heterossexismo e da heteronormatividade nas relaçóes de trabalho: a discriminação de homossexuais por homossexuais. Revista de Administração Mackenzie, 14(4), 727-742.

Valenzuela, C. C. (2016). No hay cuerpo sin imagen: visualidade gay y política virtual em tempos liberales. Universitas Humanistica, 81, 59-87.

Van De Wiele, C., \& Tong, S. T. (2014). Breaking boundaries: the uses \& gratifications of Grindr. In: Proceedings of the 2014 ACM International Joint Conference on Pervasive and Ubiquitous Computing, New York, NY, USA.

Warner, M. (Ed.). (1993). Fear of a queer planet (6th ed.). Minneapolis: University of Minnesota. 